\title{
ARTIKELEN
}

\section{Criminaliteitsconcentraties en microplaatsen}

\author{
Een toets van de 'law of crime concentration at places'
}

Wim Hardyns, Thom Snaphaan \& Lieven J.R. Pauwels

De niveaus waarop ruimtelijke concentraties van criminaliteit worden bestudeerd, worden steeds kleiner. In deze studie wordt nagegaan in welke mate criminaliteitsconcentraties zich manifesteren op het niveau van microplaatsen. Weisburd ontdekte een wetmatigheid voor wat betreft criminaliteitsconcentraties op microplaatsen en benoemde deze met de 'law of crime concentrations at places'. Deze wetmatigheid houdt in dat binnen een stedelijke context een beperkt bereik van microplaatsen geassocieerd is met een specifieke cumulatieve proportie van criminaliteit (bijv. 25 of 50 procent van de criminaliteit in een stad). In deze bijdrage onderzoeken de auteurs de stelling van Weisburd in twee Belgische grootsteden. Hiervoor werden de officiële politionele criminaliteitsstatistieken (PCS) voor de periode 2004-2012 gebruikt. Een microplaats wordt op verschillende manieren gedefinieerd en geoperationaliseerd. Daarom wordt in deze studie eveneens onderzocht of de keuze voor een bepaalde eenheid van analyse implicaties heeft voor de criminaliteitsconcentraties. De analyses werden uitgevoerd op gridniveau (aan de hand van gridcellen van 200 meter bij 200 meter) en op het niveau van de statistische sector (min of meer vergelijkbaar met viercijferige postcodegebieden of CBSbuurten). Uit deze studie blijkt dat de criminaliteitsconcentraties op gridniveau in dezelfde lijn liggen als de bevindingen van Weisburd. Deze trend is consistent, zowel over de verschillende jaren als voor de verschillende delicttypes en de twee betrokken grootsteden. De concentraties op het niveau van de statistische sector blijken beduidend minder sterk en liggen bijgevolg niet in lijn met de 'law of crime concentration at places'.

\section{Inleiding}

Microplaatsen zijn kleine geografische locaties die de laatste jaren steeds prominenter aanwezig zijn in empirisch onderzoek vanuit de omgevingscriminologie. ${ }^{1}$ De crime and place-traditie focust primair op deze micro-eenheden van analyse, zoals adressen, straatsegmenten of clusters van deze eenheden (Weisburd e.a., $2009 b)$. Het valt meteen op dat micro-eenheden vaak op verschillende manieren worden gedefinieerd, en als gevolg daarvan ook verschillend worden geoperationaliseerd. Zo definiëren Sherman e.a. een 'plaats' als: 'a fixed physical environment that can be seen completely and simultaneously, at least on its surface, by

1 Op basis van een analyse van verschillende jaargangen van het toonaangevende tijdschrift Criminology, het flagship journal van de American Society of Criminology, stelt Weisburd (2015) vast dat microplaatsen in de periode 1990-2014 slechts in 4,3 procent van de publicaties voorkomen. Tussen 2010 en 2014 was dit al in meer dan 6 procent van de publicaties het geval. 
one's naked eyes' (Sherman e.a., 1989, 31), terwijl microplaatsen door Eck en Weisburd $(1995,3)$ gedefinieerd worden als 'specific locations within the larger social environment'.

Binnen deze traditie ligt de focus niet zozeer op het 'waarom' van normoverschrijdend gedrag, maar op het 'waarom op bepaalde plaatsen en tijdstippen' concentraties van normovertredingen ontstaan. Deze traditie vindt haar oorsprong in diverse stedelijke tradities: ze combineert aspecten uit de situationele criminaliteitspreventie (Weisburd e.a., 2009a), stadsplanning en stedelijk ontwerp (urban design; zie Jeffery, 1971) en de stedelijke architectuur (urban architecture; zie Newman, 1972). Hierdoor kregen ook kenmerken van de fysieke ruimte en criminele gelegenheid (Eck \& Weisburd, 1995) een plaats naast de al langer gekende sociale ecologie (Reiss \& Tonry, 1986; Byrne \& Sampson, 1986; Wikström, 2007), die meer de nadruk legde op buurten (hogere aggregatieniveaus dan microplaatsen) als voedingsbodem of trekpleister voor zowel criminaliteitsconcentraties als onveiligheidsbeleving (Covington \& Taylor, 1991).

Een van de belangrijkste bevindingen binnen de crime and place-traditie is dat criminaliteit zich concentreert binnen een relatief beperkt aantal microplaatsen (Wilcox \& Eck, 2011). Herhaaldelijke vaststellingen met betrekking tot criminaliteitsconcentraties ${ }^{2}$ in grootsteden hebben geleid tot de formulering van een algemene wetmatigheid, ook wel de law of crime concentration at places genoemd (zie infra). Deze wetmatigheid is tot op heden hoofdzakelijk, maar niet exclusief, in Amerikaanse context getoetst (Lee e.a., 2017). In deze bijdrage gaan we na of deze wetmatigheid met betrekking tot criminaliteitsconcentraties op het niveau van microplaatsen ook opgaat in een West-Europese context. Door microplaatsen op verschillende manieren te definiëren en operationaliseren wordt daarenboven onderzocht in welke mate de gekozen eenheid van analyse leidt tot andere resultaten.

De structuur van deze bijdrage is als volgt. We starten met een niet-exhaustief overzicht van studies naar de zogenaamde 'wet van criminaliteitsconcentraties' (onze vertaling van law of crime concentrations). Vervolgens bespreken we de doelstellingen van onze studie, de gebruikte data en methoden, en de resultaten. We eindigen met de vraag wat deze bijdrage impliceert voor het (toekomstig) empirisch onderzoek naar de ruimtelijke concentraties van criminaliteit.

\section{Weisburds wet van criminaliteitsconcentraties}

Reeds in 1989 vonden Sherman e.a. (1989) dat er sprake was van sterke concentraties van criminaliteit op een heel beperkt aantal plaatsen in een stad. Zo ontdekten zij dat in Minneapolis (Minnesota) slechts 3,3 procent van de plaatsen verantwoordelijk was voor 50,4 procent van de oproepen naar de politie $(\mathrm{N}=323.979)$. Deze concentratie werd zelfs expliciet groter wanneer men ze voor afzonderlijke misdrijven ging bestuderen. Zo bleek voor diefstal $(\mathrm{N}=4.166)$, auto-

2 Met criminaliteitsconcentraties bedoelen we in deze bijdrage concentraties van gebeurtenissen die onder de juridische term van criminaliteit vallen op microplaatsniveau. 
diefstal $^{3}(\mathrm{~N}=3.908)$ en zedendelicten ${ }^{4}(\mathrm{~N}=1.729)$ dat respectievelijk 2,2, 2,7 en 1,2 procent van alle plaatsen (ca. 115.000 adressen) verantwoordelijk waren voor 100 procent van de oproepen aan de politie. We moeten er uiteraard wel rekening mee houden dat er in dit voorbeeld veel minder feiten zijn dan microplaatsen (adressen in dit geval). Bij maximale spreiding zouden diefstallen $(\mathrm{N}=4.166)$ bijvoorbeeld in maximaal 3,6 procent van de microplaatsen (ca. 115.000 adressen) kunnen plaatsvinden.

Deze bevinding was een aanzet voor meer onderzoek naar criminaliteitsconcentraties op microplaatsen. Verschillende studies in de Verenigde Staten stellen sinds eind jaren tachtig een significante concentratie van criminaliteit vast op microplaatsen in diverse steden (Pierce e.a., 1988; Weisburd e.a., 2004; Braga e.a., 2010; Weisburd, 2015). Buiten de Verenigde Staten vinden we pas recent gelijkaardige studies. Zo onderzochten Andresen en Malleson (2011) de criminaliteitsconcentraties in Vancouver (Canada), Andresen en Linning (2012) in Ottawa (Canada), Weisburd en Amran (2014) in Tel Aviv (Israël), Melo e.a. (2015) in Campinas (Brazilië), en Steenbeek en Weisburd (2015) in Den Haag (Nederland). Recent voerden Lee e.a. (2017) een systematische review uit waarin 44 studies (waarvan negen betrekking hadden op een niet-Amerikaanse context) geïncludeerd werden, waaronder de voornoemde studies. Alle komen zij tot dezelfde conclusie: criminaliteit is op microplaatsniveau niet evenredig verdeeld over de betreffende micro-eenheden van analyse.

Weisburd e.a. (2012) kwamen in hun longitudinaal onderzoek naar criminaliteitsconcentraties in Seattle (Washington) tot vijf hoofdconclusies:

- Criminaliteit is sterk geconcentreerd binnen zogenaamde hot spots, wat inhoudt dat een klein aantal plaatsen verantwoordelijk is voor een grote proportie criminaliteit (cf. Sherman e.a., 1989).

- De concentratie van criminaliteit is consistent over de tijd heen en criminaliteit concentreert zich ook op dezelfde plaatsen.

- Criminaliteit kent een sterke variabiliteit op het microniveau, het gebruik van hogere aggregatieniveaus leidt tot informatieverlies.

- Niet enkel criminaliteit vertoont een sterke variabiliteit op het microniveau, ook sociale en contextuele kenmerken van plaatsen variëren op dit niveau.

- Criminaliteit in de ruimte is voorspelbaar, wat het mogelijk maakt om, naast het begrijpen van de criminaliteitsconcentraties, effectieve preventiestrategieën toe te passen op de betreffende hot spots.

Voorgaande onderzoeksresultaten inspireerden Weisburd (2015) tot een metaanalyse. Op basis van deze studie kon hij vaststellen dat 50 procent van de criminaliteit in steden voorkomt in 2,1 tot 6,0 procent van de bestudeerde microplaatsen en 25 procent van de criminaliteit in 0,4 tot 1,6 procent van de bestudeerde microplaatsen. In een latere publicatie (Weisburd e.a., 2016) legt hij de lat voor 50

3 Autodiefstal is hier een aggregaat van verschillende oproepcodes, inclusief pogingen tot autodiefstal en alarmen (Sherman e.a., 1989).

4 Zedendelicten is hier een aggregaat van de delicten 'rape', 'molesting' en 'exposing' (Sherman e.a., 1989). 
procent van de criminaliteit op ongeveer 4 procent van de microplaatsen en 25 procent van de criminaliteit op minder dan 1,5 procent van de microplaatsen.

Op basis van deze herhaaldelijke vaststellingen formuleerde David Weisburd zijn intussen gekende law of crime concentration at places: 'for a defined measure of crime at a specific microgeographic unit, the concentration of crime will fall within a narrow bandwidth of percentages for a defined cumulative proportion of crime' (Weisburd, 2015,138). Deze wet stelt dat, voor een specifiek delicttype, een beperkt percentage (c.q. bandbreedte) microplaatsen verantwoordelijk is voor een specifieke cumulatieve proportie van criminaliteit (bijv. 25 of 50 procent van de criminaliteit in een stad). De klemtoon op het delicttype is van belang, aangezien de concentratie van criminaliteit verschilt naarmate andere criminaliteitsvormen worden bestudeerd.

De keuze voor bepaalde cutoff waarden, zoals 25 of 50 procent van de criminaliteit in een stad, kan gezien worden als arbitrair. Om dit te ondervangen pleiten Bernasco en Steenbeek (2016) voor het weergeven van de volledige cumulatieve verdeling. Zij adviseren het gebruik van de (gestandaardiseerde) Lorenz-curve en de Gini-coëfficiënt wanneer gerapporteerd wordt over criminaliteitsconcentraties. De Lorenz-curve is een weergave van de cumulatieve verdeling van een variabele (bijv. criminaliteit c.q. aantal delicten) ten opzichte van de cumulatieve verdeling van analyse-eenheden (bijv. plaatsen c.q. gridcellen). Bernasco en Steenbeek $(2016,4)$ beklemtonen de meerwaarde van de Lorenz-curve:

'Applied to the distribution of crimes across places, the Lorenz curve plots cumulative percentages of crime on the vertical axis against cumulative percentages of places on the horizontal axis, with the places ordered by number of crimes. Thus, each and every point on the curve corresponds to a statement like "Y percent of crimes occur in the X percent most targeted places". In other words, the Lorenz curve includes in a single graph all cumulative percentage statements that can be made about a given crime distribution! By presenting the Lorenz curve there is no longer any need to decide on a cutoff value for $\mathrm{X}$ or for $\mathrm{Y}$, as all are included.'

De Gini-coëfficiënt is een getal dat de mate van concentratie in een verdeling uitdrukt. Deze coëfficiënt werd meer dan een eeuw geleden ontwikkeld om de mate van inkomensongelijkheid uit te drukken. De waarde 0 correspondeert met 'perfecte gelijkheid', i.c. geen criminaliteitsconcentratie, of ook: op alle plaatsen werden evenveel delicten gepleegd. De waarde 1 correspondeert met 'perfecte ongelijkheid', i.c. maximale criminaliteitsconcentratie, of ook: op één plaats werden alle delicten gepleegd. De berekening van de Gini-coëfficiënt wordt op uiteenlopende (equivalente) manieren weergegeven. Bernasco en Steenbeek (2016) berekenen de Gini-coëfficiënt in het kader van criminaliteitsconcentratie als volgt:

$$
G=\left(\frac{1}{n}\right)\left(2 \sum_{i=1}^{n} i y_{i}-n-1\right)
$$


In deze formule staat $G$ voor de Gini-coëfficiënt, $n$ voor het aantal plaatsen, $y i$ voor de proportie criminaliteit in $i$ (waarbij de waarde 1 staat voor alle criminaliteit) en $i$ voor het rangnummer van de plaats wanneer alle plaatsen van hoog naar laag worden gerangschikt op basis van het aantal delicten $y$.

Eerder haalden we de beperking reeds aan van het uitdrukken van criminaliteitsconcentraties wanneer er minder criminele feiten (c) zijn dan eenheden van analyse (n). Bernasco en Steenbeek (2016) lichten toe dat ook de interpretatie van de Lorenz-curve en de Gini-coëfficiënt problematisch is in dergelijke gevallen. Zelfs wanneer er sprake zou zijn van een perfecte gelijkmatige verdeling van criminele feiten over de eenheden van analyse, zou criminaliteit zich immers nog concentreren binnen slechts een klein aantal eenheden. In deze gevallen, wanneer $c<n$, adviseren Bernasco en Steenbeek (2016) het gebruik van een gestandaardiseerde Lorenz-curve en gestandaardiseerde Gini-coëfficiënt ( $\left.G^{\prime}\right)$ :

$$
G^{\prime}=\max \left(\frac{n}{c}, 1\right)(G-1)+1
$$

Deze gestandaardiseerde Gini-coëfficiënt kan ook berekend worden zonder gebruik te maken van de reguliere Gini-coëfficiënt. In dat geval gebruikt men de volgende formule:

$$
G^{\prime}=\max \left(\frac{1}{c^{\prime}}, \frac{1}{n}\right)\left(2 \sum_{i=1}^{n}\left(i y_{i}\right)-n-1\right)-\max \left(\frac{n}{c}, 1\right)+1
$$

Weisburd baseerde zich bij de formulering van zijn wetmatigheid op het straatsegment als analyse-eenheid. Een straatsegment wordt gedefinieerd als het gedeelte van een straat dat gelegen is tussen twee kruispunten (intersections). In de onderzochte steden in de Verenigde Staten kent men city blocks, wat maakt dat de straatsegmenten over het algemeen tamelijk gelijke lengten hebben. Dit typische dambordpatroon van Amerikaanse grootsteden maakt het tot een gebruiksvriendelijk analyseniveau in deze context. Europese grootsteden kennen dit dambordpatroon niet, waardoor de straatsegmenten zeer verschillende lengten hebben. Langere straatsegmenten hebben bijgevolg logischerwijs meer kans op criminaliteitsconcentraties dan kleinere straatsegmenten. Verderop in deze bijdrage bespreken we een alternatief voor het straatsegment als analyse-eenheid, dat ons inziens beter aansluit bij de morfologie van de onderzochte steden.

Weisburd $(2015,151)$ stelt verder:

'I have focused on a first law of the criminology of place - the law of crime concentration at places. I have presented new evidence showing that the law applies with startling consistency both across cities and within cities across time. The data suggest that the law of crime concentration is a "general proposition of universal validity" (Sutherland, 1947:23), analogous to physical laws observed in the natural sciences.' 
Dit is wat Popper 'a bold statement' zou genoemd hebben: general validity is een sterke claim, die om replicastudies vraagt. Het concept 'law' mag vanuit deze traditie niet geïnterpreteerd worden als een Hempeliaanse wetmatigheid, i.e. een covering law-verklaring. ${ }^{5}$ Overigens dient opgemerkt te worden dat deze beschrijvende wetmatigheid nog vele vragen oproept, niet in het minst een adequate verklaring over de mechanismen die schuilgaan achter deze wetmatigheid (zie Bruinsma \& Pauwels, 2017 voor een discussie).

\section{Doelstelling van deze studie}

Deze studie heeft als doel de bevindingen van Weisburd zo goed als mogelijk te repliceren in de Belgische stedelijke context, die toch een andere geografische, functionele en morfologische structuur heeft dan de Noord-Amerikaanse. Door microplaatsen op verschillende manieren te definiëren en operationaliseren willen we daarenboven nagaan in welke mate de gekozen eenheid van analyse andere resultaten laat zien. We opteren er daarom voor te spreken van een partiële toets, aangezien we noodgedwongen (gegeven de Belgische context) ietwat verschillende operationalisaties van microplaatsen hanteren en bovendien meerdere analyse-eenheden in dit onderzoek betrekken. ${ }^{6}$

Met deze partiële toets willen we empirisch onderzoeken of de law of crime concentration at places zich manifesteert in twee Belgische grootsteden. ${ }^{7}$ Hoewel de vraag beschrijvend is, draagt het antwoord bij tot het verhogen van de kennis over de veralgemeenbaarheid van de beschrijvende wetmatigheid. Daarnaast beantwoorden we een methodologische onderzoeksvraag, die onlosmakelijk verbonden is met de beschrijvende vraag: heeft het aggregatieniveau een impact op de manifestatie van de wetmatigheid?

De empirische toets wordt uitgevoerd op twee analyseniveaus, te weten het niveau van de statistische sector en het gridniveau (zie infra). De keuze voor deze twee niveaus is zowel inhoudelijk als pragmatisch: de morfologie van de onderzochte steden maakt dat het straatsegmentniveau, zoals gebruikt door Weisburd, minder geschikt is, waardoor alternatieven wenselijk zijn. Belgische steden kunnen geografisch makkelijk worden opgedeeld in gridcellen en statistische sectoren (het Belgische equivalent van de Nederlandse CBS-buurten). Er is gekeken naar

5 Covering law-verklaringen waren lange tijd een dominant verklaringsmodel, maar dit model is om verschillende redenen in onbruik geraakt (wie in deze discussie geïnteresseerd is, verwijzen we naar Opp (2005) en Kalter en Kroneberg (2014)). De law of crime concentrations is geen verklaring, aangezien niet wordt verklaard onder welke condities die concentraties opgaan en welke mechanismen verantwoordelijk zijn voor deze concentraties. Met law bedoelt Weisburd wel degelijk een empirische generalisatie (Bunge, 1999).

6 Echte replicaties zijn helaas zeldzaam in ons vakgebied en verhinderen de veralgemening en kennisaccumulatie. Vaak moeten we echter roeien met de riemen die we hebben en rekening houden met contextspecifieke kenmerken die een exacte replicatie verhinderen.

7 Op vraag van de politiediensten gebruiken we in deze bijdrage niet de stadsnamen, maar spreken we van Stad X en Stad Y. Aangezien deze bijdrage focust op het toetsen van de law of crime concentration at places, en niet als doel heeft steden met elkaar te vergelijken, heeft dit verder geen enkele implicatie. 
zowel de mate van criminaliteitsconcentratie op beide niveaus als de consistentie van deze concentraties over de tijd heen. Op die manier is het mogelijk om na te gaan of de wetmatigheid ook voor België opgaat. Daarnaast wordt gebruikgemaakt van de Lorenz-curve en de Gini-coëfficiënt om de criminaliteitsconcentraties zo volledig mogelijk weer te geven (zoals in Bernasco en Steenbeek, 2016). Dit werd nooit eerder onderzocht in deze context.

\section{Operationalisatie van microplaatsen}

Sociaalecologische en omgevingscriminologische studies zijn vaak gebaseerd op geografische eenheden die omwille van administratieve doeleinden zijn opgesteld. Het analyseren van criminologische data op te grote geografische eenheden kan echter geografische variabiliteit, die aanwezig is op een lager niveau, maskeren. Dit kan implicaties hebben voor de validiteit van het onderzoek. Volgens Rengert en Lockwood (2009) zou het betrekken van meerdere geografische aggregatieniveaus net zo vanzelfsprekend moeten zijn als het betrekken van meerdere onafhankelijke variabelen in het toetsen van statistische significantie. Dit maakt het namelijk mogelijk om te bepalen of de keuze voor een bepaald aggregatieniveau resulteert in vertekende bevindingen.

Om te weten of de bevindingen onderhevig zijn aan het aggregatieniveau (beter gekend als het Modifiable Areal Unit Problem of MAUP), bestuderen we de criminaliteitsconcentraties op twee niveaus, met name het statistische-sectorniveau en het gridniveau. MAUP, ofwel het probleem inzake de schaalbaarheid van ruimtelijke eenheden, weerspiegelt het probleem van het kiezen van het juiste aggregatieniveau (Dark \& Bram, 2007). De centrale stelling bij dit probleem is dat identieke data, die op verschillende manieren worden geaggregeerd, kunnen leiden tot andere resultaten. Er zijn twee kernproblemen die hun invloed hebben op de schaalbaarheid: het probleem van welk aggregatieniveau het meest adequaat is in een bepaald onderzoek (zonation effect) en het probleem hoe men de data aggregeert naar een hoger aggregatieniveau (scale effect) (Oberwittler \& Wikström, 2009). Er zijn beduidend minder statistische sectoren in vergelijking met gridcellen. Statistische sectoren bestaan uit meerdere gridcellen en verschillen in omvang van elkaar: in Stad X telt een statistische sector gemiddeld 18 gridcellen, in Stad Y gemiddeld 21 gridcellen. We lichten hieronder de verschillen tussen beide niveaus verder toe.

\section{De statistische sector als analyse-eenheid}

Het niveau van de statistische sector is het laagste aggregatieniveau in België waarop administratieve data worden verzameld en is bijgevolg een zeer interessante eenheid van analyse. Het niveau van de statistische sector wordt vaak gehanteerd in criminologisch onderzoek dat neighbourhoods of buurten bestudeert (Hardyns e.a., 2015) en is min of meer vergelijkbaar met het niveau van de Nederlandse CBS-buurten. Statistische sectoren kunnen verschillen qua bevolkingsomvang en oppervlakte. Anno 2016 telde Stad X 298 statistische sectoren en Stad Y 201 statistische sectoren. 


\section{De gridcel als analyse-eenheid}

Het gridniveau wordt gecreëerd door een gelijkmatig raster over een geografisch gebied te leggen. Dit analyseniveau wordt projectmatig reeds op kleine schaal gebruikt en zal mogelijk aan belang winnen in de toekomst (zie bijv. Rummens e.a., 2017). Het voordeel van het gridniveau ten opzichte van het straatsegmentniveau is dat gridcellen een vaste afmeting hebben, terwijl dit bij de operationalisatie op straatsegmentniveau niet het geval is (zie supra). In het kader van dit onderzoek werd gebruikgemaakt van gridcellen van 200 meter bij 200 meter. Stad $\mathrm{X}$ telt 5.403 gridcellen, Stad Y telt 4.254 gridcellen.

\section{Data}

In het kader van dit onderzoek werd gebruikgemaakt van de politionele criminaliteitsstatistieken van twee Belgische grootsteden over een tijdspanne van negen jaar (c.q. 2004 tot en met 2012). Om het aantal delicten ten opzichte van het aantal plaatsen te verhogen, hebben we ervoor gekozen de criminaliteitscijfers van verschillende jaren samen te bestuderen. De data werden gegeocodeerd en geoperationaliseerd op het niveau van de statistische sector en op het gridniveau. Er werden drie zogenaamde criminele figuren bestudeerd: woninginbraak, opzettelijke slagen en verwondingen en agressieve diefstal. In de Belgische criminaliteitsstatistiek (de fenomeenstatistiek) spreken we van criminele figuren wanneer het fenomeen slechts kan gecreëerd worden door de juridische kwalificatie te combineren met bijkomende informatie uit het oorspronkelijke proces-verbaal, dat door de lokale politie ingevoerd wordt in de lokale databanken. De criminele figuur woninginbraak is samengesteld uit: diefstal in woning zonder geweld, diefstal in woning met geweld en zonder wapens, en diefstal in woning met geweld en met wapens. De criminele figuur opzettelijke slagen en verwondingen betreft politionele registraties voor: opzettelijke slagen, geweld, vechtpartijen, hondenbeten, foltering, onmenselijke behandeling, onterende behandeling, toedienen van schadelijke stoffen en onthouding van voedsel of verzorging. De criminele figuur agressieve diefstal bevat: handtasroof, diefstal met geweld en diefstal met vertoon of gebruik van een wapen; het is een delicttype dat kenmerken heeft van zowel een vermogensdelict als een geweldsdelict.

Per delicttype werd de precisie van de plaatsaanduiding nagegaan (zie tabel 1 en 2). De kwaliteit van geografisch onderzoek staat of valt met de methodologische problemen die zich kunnen voordoen op geografisch niveau: eerdere Belgische studies toonden aan dat voor diverse criminaliteitsvormen het aantal correct ingevulde processen-verbaal met plaatsbepaling sterk varieert en dat deze geocodeerbare informatie hoger is voor criminaliteitsvormen met een immobiel doelwit dan voor criminaliteitsvormen met een mobiel doelwit (Pauwels, 2002). In geval van een ontbrekende straat rest ons helaas geen andere mogelijkheid dan deze delicten te verwijderen uit de dataset. In geval van een ontbrekend huisnummer werd gezocht naar een gepaste en methodologisch verdedigbare toewijzingsmethode (aan een grid of statistische sector) om op die manier zo veel mogelijk gegevens te behouden voor de analyses. Voor Stad X hebben we ons gebaseerd op een 
Tabel 1 Precisie plaatsaanduiding Stad X 2004-2012

\begin{tabular}{|c|c|c|c|}
\hline \multicolumn{4}{|l|}{ Stad X } \\
\hline & $\mathbf{N}$ & Ontbrekende straat & Ontbrekend huisnummer \\
\hline \multicolumn{4}{|l|}{ Agressieve diefstal } \\
\hline Diefstal met geweld & 11.003 & $2,0 \%(221)$ & $67,5 \%(7.424)$ \\
\hline Diefstal met wapen & 3.490 & $2,2 \%(77)$ & $52,1 \%(1.820)$ \\
\hline Handtasroof & 4.545 & $1,2 \%(54)$ & $69,0 \%(3.138)$ \\
\hline Slagen en verwondingen & 52.727 & $\mathrm{I}, 0 \%(536)$ & $36,4 \%(19.195)$ \\
\hline Woninginbraak & 43.901 & $0,2 \%(70)$ & $2,0 \%(878)$ \\
\hline
\end{tabular}

Tabel 2 Precisie plaatsaanduiding Stad Y 2004-2012

\begin{tabular}{llll}
\hline Stad $\mathbf{Y}$ & & & \\
& $\mathbf{N}$ & Ontbrekende straat & Ontbrekend huisnummer \\
\hline Agressieve diefstal & & & \\
Diefstal met geweld & $3.50 \mathrm{I}$ & $2,9 \%(103)$ & $58,9 \%(2.06 \mathrm{I})$ \\
Diefstal met wapen & 206 & $\mathrm{I}, 5 \%(3)$ & $18,0 \%(37)$ \\
Handtasroof & 1.299 & $\mathrm{I}, 0 \%(13)$ & $66,1 \%(859)$ \\
Slagen en verwondingen & 29.035 & $4,6 \%(1.339)$ & $37,3 \%(10.837)$ \\
Woninginbraak & 13.567 & $0,7 \%(90)$ & $2,7 \%(370)$ \\
\hline
\end{tabular}

toewijzingsmethode uit een voorgaand onderzoek (zie Rummens e.a., 2017), waarbij een delict wordt toegewezen aan een gridcel op basis van een kansberekening gebaseerd op het aandeel van elke cel in de oppervlakte van de straat. Voor Stad Y werden de delicten in het geval van een ontbrekend huisnummer toegewezen op basis van de coördinaten van het midden van de straat. De politionele data van Stad Y konden op die manier worden gegeocodeerd met een hit rate van 99,21 procent. De adressen die niet gegeocodeerd zijn, zijn voornamelijk parken en pleinen. Hierboven wordt een overzicht gegeven van de ontbrekende data voor Stad $\mathrm{X}$ (tabel 1) en Stad Y (tabel 2).

Uit tabel 1 blijkt dat een ontbrekend huisnummer vaker een probleem is dan een ontbrekende straat (variatiebreedte van 0,2 tot 2,2 procent bij ontbrekende straat en van 2,0 tot 69,0 procent bij ontbrekend huisnummer). Een ontbrekend huisnummer lijkt samen te hangen met de aard van het doelwit (mobiel versus immobiel): bij woninginbraken is het bijna inherent aan het fenomeen te verwachten dat het huisnummer gekend is. Toch stellen we ook daar een beperkte onvolledige registratie vast.

Wanneer we de data voor Stad Y bekijken (tabel 2), dan komt een gelijkaardig patroon tevoorschijn. Een ontbrekende straat (variatiebreedte van 0,7 tot 4,6 
Tabel 3 Aantal delicten per delicttype op gridniveau en niveau van de statistische sector (Stad Y)

\begin{tabular}{lll}
\hline & N criminaliteit grid & N criminaliteit statistische sector \\
\hline $\begin{array}{l}\text { Agressieve dief- } \\
\text { stal }\end{array}$ & 4.723 & 4.709 \\
$\begin{array}{l}\text { Slagen en ver- } \\
\text { wondingen }\end{array}$ & 27.496 & 27.403 \\
Woninginbraak & 13.410 & 13.381 \\
\hline
\end{tabular}

procent) is minder problematisch dan een ontbrekend huisnummer (variatiebreedte van 2,7 tot 66,1 procent).

Gegeven het feit dat het niveau van de statistische sector en het gridniveau morfologisch niet perfect congruent zijn, is het logisch dat er kleine verschillen optreden in het aantal geregistreerde delicten naargelang het aggregatieniveau. Dit wordt veroorzaakt door de vorm van de gridcellen, die buiten de grenzen kunnen vallen van de statistische sector. In tabel 3 wordt het aantal delicten per aggregatieniveau weergegeven voor Stad Y. Deze morfologische incongruentie doet zich enkel voor bij Stad Y. Omwille van een andere methode van geocodering (zie supra) zijn de aantallen delicten in Stad X voor beide aggregatieniveaus exact hetzelfde.

\section{Resultaten}

We bespreken in deze paragraaf de criminaliteitsconcentraties voor de onderscheiden vormen van geregistreerde criminaliteit op het gridniveau en op het statistische-sectorniveau. We spreken van criminaliteitsconcentraties in termen van de prevalentie (alle plaatsen) en niet op basis van de frequentie (plaatsen waar criminaliteit geregistreerd werd) van criminaliteit (zie ook Lee e.a., 2017).

\section{Gridniveau}

De resultaten tonen aan dat de onderscheiden delicttypes een zeer hoge mate van ruimtelijke clustering kennen: 25 procent van de bestudeerde delicten doet zich voor binnen respectievelijk 1,28 procent (Stad X) en 1,01 procent (Stad Y) van het totaal aantal gridcellen, 50 procent van de bestudeerde delicten doet zich voor binnen respectievelijk 4,45 procent (Stad X) en 3,44 procent (Stad Y) van het totaal aantal gridcellen. De verschillen tussen beide steden zijn minimaal, ook als we kijken naar de delictspecifieke percentages. De concentraties zijn net iets sterker in Stad Y ten opzichte van Stad X. De concentraties zijn het sterkst bij het delict agressieve diefstal, gevolgd door opzettelijke slagen en verwondingen en woninginbraak.

In figuur 1 wordt visueel weergegeven op hoeveel procent van alle gridcellen respectievelijk 25 en 50 procent van de criminaliteit zich concentreert. Zoals aange- 
geven zijn de concentraties in Stad Y iets sterker dan in Stad X, maar blijven de verhoudingen tussen de delicttypes in beide steden hetzelfde.

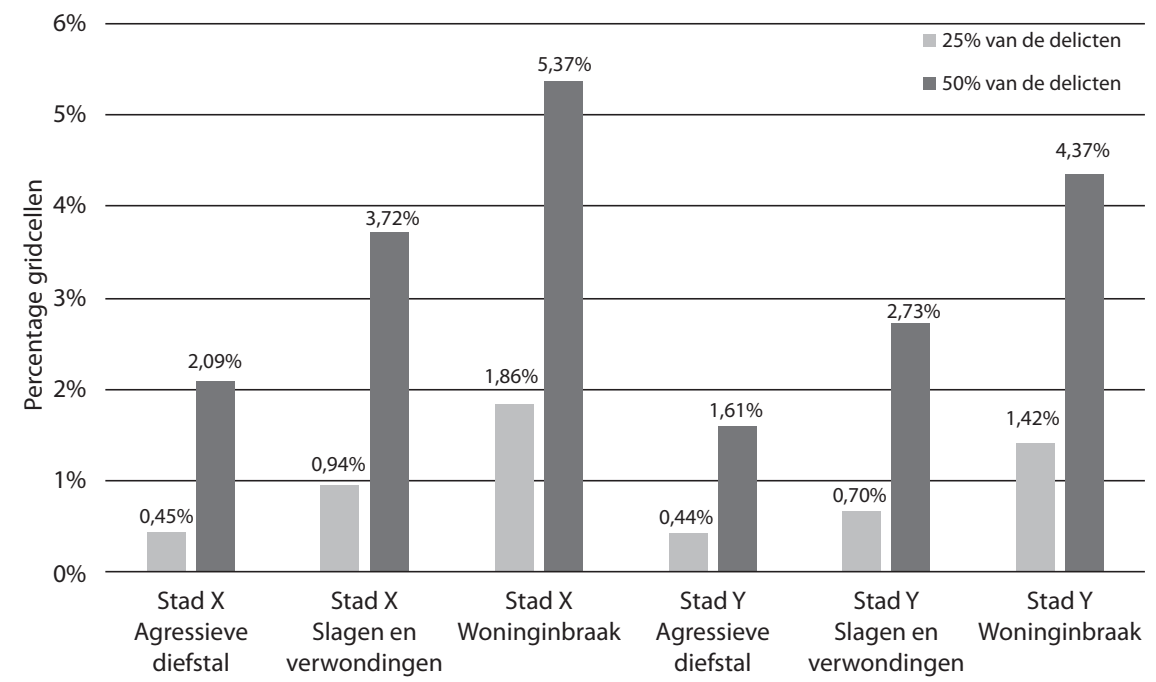

Figuur 1 De 'law of crime concentration at places' per delicttype op gridniveau (2004-2012)

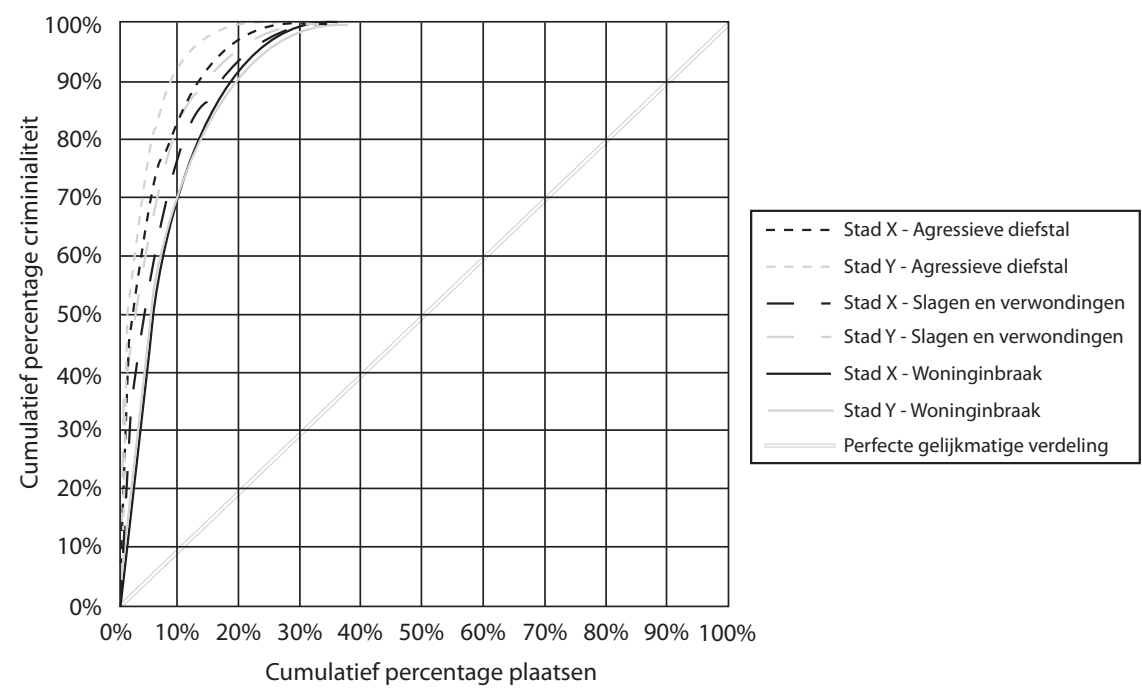

Figuur 2 Lorenz-curve van criminaliteitsdata op gridniveau

Om een vollediger beeld te krijgen van de criminaliteitsconcentraties wordt in figuur 2 de cumulatieve verdeling van de criminaliteitsconcentratie op gridniveau voor de drie delicttypes weergegeven in een Lorenz-curve. 


\section{Statistische-sectorniveau}

Op het niveau van de statistische sector is nog steeds sprake van een hoge mate van ruimtelijke clustering. Opvallend is dat de clustering minder uitgesproken is dan op het gridniveau: 25 procent van de delicten doet zich voor binnen respectievelijk 6,13 procent (Stad X) en 3,78 procent (Stad Y) van het totaal aantal statistische sectoren, 50 procent van de delicten doet zich voor binnen respectievelijk 16,83 procent (Stad X) en 11,02 procent (Stad Y) van het totaal aantal statistische sectoren. De concentraties zijn sterker in Stad Y ten opzichte van Stad X, en zijn opnieuw het sterkst bij het delict agressieve diefstal, gevolgd door opzettelijke slagen en verwondingen en woninginbraak.

In figuur 3 wordt visueel weergegeven in hoeveel procent van alle statistische sectoren respectievelijk 25 en 50 procent van de criminaliteit zich concentreren. Ook hier blijven de verhoudingen tussen de delicttypes in beide steden hetzelfde.

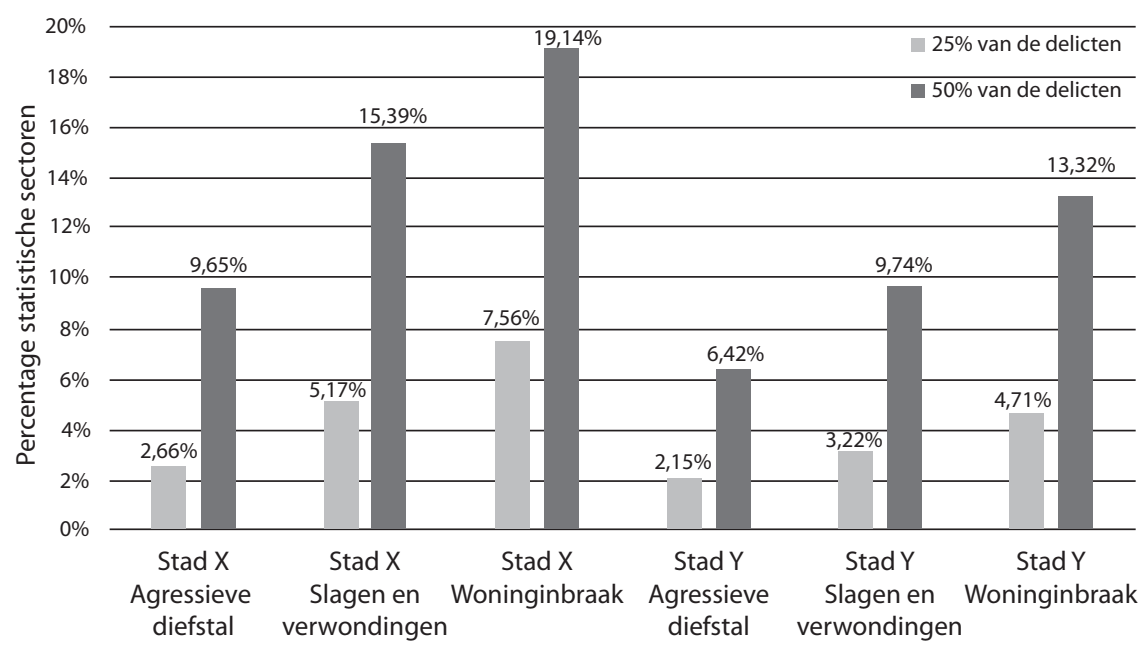

Figuur 3 De 'law of crime concentration at places' per delicttype op statistischesectorniveau (2004-2012) 


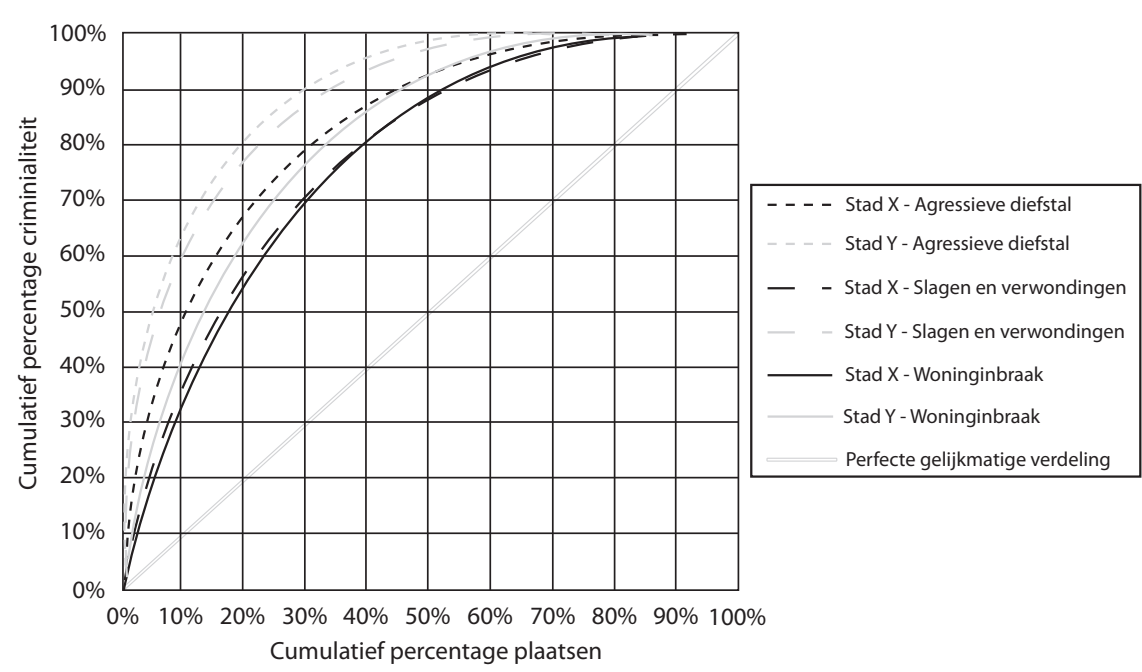

Figuur 4 Lorenz-curve van criminaliteitsdata op niveau van de statistische sector

Om een vollediger beeld te krijgen van de criminaliteitsconcentraties wordt in figuur 4 de cumulatieve verdeling van de criminaliteitsconcentratie op statistische-sectorniveau voor de drie delicttypes weergegeven in een Lorenz-curve. In vergelijking met figuur 2 zien we duidelijk dat een groter aandeel statistische sectoren geconfronteerd wordt met delicten binnen de verschillende delicttypes, daar waar een groter aandeel gridcellen buiten schot blijft. Op zich niet zo verwonderlijk als men weet dat een statistische sector bestaat uit verschillende gridcellen en dus per definitie een omvangrijker gebied beslaat.

\section{Gini-coëfficiënt gridniveau en statistische-sectorniveau}

Zoals in het begin van deze bijdrage besproken, kunnen we criminaliteitsconcentraties ook uitdrukken door middel van één getal: de Gini-coëfficiënt. In tabel 4 worden de Gini-coëfficiënten per delicttype en per analyseniveau weergegeven voor beide steden.

Deze Gini-coëfficiënten bevestigen bovenstaande analyses: de criminaliteitsconcentraties zijn beduidend sterker op het gridniveau dan op het niveau van de statistische sector (de waarden liggen dichter bij 1). Tevens zijn de concentraties voor alle onderzochte delicttypes sterker in Stad Y ten opzichte van Stad X. 
Tabel 4 Gini-coëfficiënt per delicttype en per analyseniveau voor Stad X en Stad $Y$

\begin{tabular}{lllll}
\hline Delicttype & Stad & $\begin{array}{l}\text { Totale criminaliteit } \\
\mathbf{2 0 0 4 - 2 0 ~ I ~ 2 ~}\end{array}$ & Gini-coëfficiënt grid & $\begin{array}{l}\text { Gini-coëfficiënt } \\
\text { statistische sector }\end{array}$ \\
\hline Agressieve & $\mathrm{X}$ & $\mathbf{1 8 . 5 1 8}$ & 0,91 & 0,66 \\
diefstal & Y & 4.723 & 0,94 & 0,80 \\
Slagen en & $\mathrm{X}$ & 51.848 & 0,87 & 0,56 \\
verwondingen & Y & 27.496 & 0,90 & 0,70 \\
Woninginbraak & $\mathrm{X}$ & 43.760 & 0,85 & 0,52 \\
& Y & 13.410 & 0,86 & 0,62 \\
\hline
\end{tabular}

\section{Besluit en discussie}

Weisburd (2015) beargumenteerde dat er sprake is van een geografische wetmatigheid inzake de concentratie van criminaliteit op microplaatsen. Met zijn law of crime concentration at places stelt hij dat een bepaald bereik van percentages microplaatsen (de bandbreedte) verantwoordelijk is voor een specifieke cumulatieve proportie van criminaliteit (bijv. 25 of 50 procent van de criminaliteit in een stad). De concentratie van 50 procent van de criminaliteit in steden situeert zich in ongeveer 4 procent van de microplaatsen en 25 procent van de criminaliteit situeert zich in minder dan 1,5 procent van de microplaatsen.

In deze bijdrage stelden we ons tot doel na te gaan in welke mate de bevindingen van Weisburd ook opgingen in twee Belgische grootsteden, en of deze resultaten door de keuze voor een bepaalde aggregatieniveau worden beïnvloed. Hiervoor hebben we gebruikgemaakt van twee verschillende aggregatieniveaus: het gridniveau en het statistische-sectorniveau. De resultaten op gridniveau liggen volledig in de lijn van Weisburds bevindingen: 25 procent van de criminaliteit concentreert zich naargelang het delicttype en naargelang de stad tussen 0,44 en 1,86 procent van de microplaatsen, 50 procent van de criminaliteit concentreert zich tussen 1,61 en 5,37 procent van de plaatsen. Deze resultaten zijn gebaseerd op een periode van negen jaar. De kritische lezer kan zich terecht de vraag stellen in welke mate er fluctuaties bestaan per jaar en of we er wel goed aan doen zomaar deze data, afkomstig uit verschillende jaartallen, op één hoop te gooien. Daarom voegen we eraan toe dat als we de concentraties per jaar bestuderen, de concentraties nog sterker blijken te zijn. ${ }^{8}$ Dit heeft uiteraard ook te maken met een lager aantal delicten die worden geregistreerd binnen de periode van een jaar ten opzichte van negen jaar. Desalniettemin liggen de resultaten in lijn met de bevindingen van de metastudie van Lee e.a. (2017) voor wat betreft de criminaliteitsconcentraties in de Verenigde Staten en de andere bestudeerde landen.

8 Deze concentraties bleven ook consistent door de tijd heen. Dat de trend van criminaliteitsconcentratie relatief stabiel is gedurende de geanalyseerde periode, betekent echter niet per definitie dat criminaliteit zich steeds concentreert op dezelfde plaatsen. In het kader van dit artikel gaan we daar echter niet dieper op in. 
Wanneer we de concentraties op statistische-sectorniveau bekijken, zijn de concentraties minder uitgesproken en liggen de bandbreedtes niet exact in dezelfde lijn als de law of crime concentration at places, hoewel nog steeds van een manifeste concentratie kan gesproken worden. Vooral vanuit beleidsmatig perspectief zijn deze vaststellingen op dit niveau interessant. De statistische sector is immers een bekend administratief niveau bij stads- en politiediensten, waardoor men makkelijker operationeel kan werken binnen die sectoren die er het meest uitspringen. Dit is ook het laagste niveau waarop systematische dataverzameling gebeurt. In het licht van de resultaten moet echter de vraag gesteld worden of het roer dient omgegooid te worden en of we geen pleidooi dienen te houden voor meer aandacht voor kleinschaligere niveaus. De analyses op gridniveau suggereren immers dat men hierbij effectiever en efficiënter kan focussen op een beperkt aantal problematische microplaatsen, waar een groot aandeel van de criminaliteit zich manifesteert. Hoe kleiner de eenheden van analyse, hoe eenduidiger de resultaten geïnterpreteerd kunnen worden. Al blijft de vraag of het voor politiediensten überhaupt effectiever werken is door meer patrouilles te voeren in specifieke gridcellen verspreid over een stad in plaats van extra te investeren in community policing in enkele van de meest problematische buurten of wijken. Dit is een belangrijke vraag voor toekomstig onderzoek en het biedt ook perspectieven voor nieuwe onderzoeksgebieden als crime forecasting en predictive policing, waarbij men criminaliteitsconcentraties in de toekomst tracht te voorspellen (zie Rummens e.a., 2017).

Verder empirisch onderzoek van de law of crime concentration at places zal uitwijzen in welke mate deze wetmatigheid ook opgaat voor andere steden en microplaatsen. Ook binnen de bestudeerde steden kunnen nog aanvullende analyses uitgevoerd worden, bijvoorbeeld door ook andere operationalisaties van microplaatsen te bestuderen, zoals het straatsegmentniveau dat in de Amerikaanse context wordt gebruikt. Ondanks dat dit niveau, gegeven de morfologie van Belgische steden, wellicht minder bruikbaar is dan in de Amerikaanse context, is het van belang dat empirisch wordt vastgesteld in welke mate het straatsegmentniveau toepasbaar is en wat de implicaties zijn van een indeling op basis van deze microplaatsen.

De vraag stelt zich bovendien wat de randvoorwaarden en criteria zijn om de wetmatigheid al dan niet te verwerpen of bij te sturen. Bernasco en Steenbeek (2016) geven hiertoe een belangrijke aanzet. Zij stellen dat het gebruik van de (gestandaardiseerde) Lorenz-curve en Gini-coëfficiënt een beter (lees: minder arbitrair en informatiever) beeld verschaft van de criminaliteitsconcentratie. Bovendien maakt deze methode volgens de auteurs een betere vergelijking mogelijk tussen de bevindingen in verschillende contexten. De vraag blijft echter welke bandbreedte overschreden moet worden om van een verificatie van de wetmatigheid te kunnen spreken. Zonder dat hiervoor duidelijke regels worden opgesteld, is er in principe geen heldere toetsing mogelijk. In feite ligt de verantwoordelijkheid hier bij de opstellers van een theorie (in dit geval empirische wetmatigheid) om precies aan te geven hoe sterk de concentratie moet zijn, hoe consistent de concentratie dient te zijn door de tijd heen en met welke andere randvoorwaarden rekening moet worden gehouden. Deze randvoorwaarden zijn van belang, aangezien 
deze en andere studies aantonen dat het bestuderen van kortere tijdspannen of het analyseren van specifieke delicttypes implicaties heeft voor de vastgestelde criminaliteitsconcentraties. Enkel op die manier kunnen toekomstige replicatiestudies een eenduidig antwoord geven op de vraag of de law of crime concentration at places generaliseerbaar is.

Hoewel Weisburd zelf van een wetmatigheid spreekt, betreft het eerder een verhouding, die vragen oproept. Het gaat om een stabiel patroon, maar op dit moment is het nog zoeken naar een reeks van mechanismen die de processen in gang zetten die voor de wetmatigheden zorgen. Een van de volgende stappen die horen te gebeuren, is het openen van de black box. Dit is precies wat Bruinsma en Pauwels (2017) benadrukken. Daartoe is geïntegreerde theorie nodig en moet men zich de vraag stellen hoe het komt dat bepaalde interacties en criminele transacties in hoge mate in bepaalde microplaatsen plaatsvinden. Microplaatsen zijn immers geen reële actoren van vlees en bloed, maar kleine entiteiten die keuzeprocessen (in reflexieve of automatische modus) uitlokken. Een echte verklaring zal daarom ongetwijfeld een micro-meso-macro-integratie inhouden. Een vruchtbare manier om verklaringen te evalueren is door het toepassen van een vergelijkend onderzoeksprogramma dat tot doel heeft verschillende verklaringsmodellen naast elkaar te leggen.

\section{Literatuur}

Andresen, M.A. \& Linning, S.J. (2012). The (in)appropriateness of aggregating across crime types. Applied Geography, 35, 275-282.

Andresen, M.A. \& Malleson, N. (2011). Testing the stability of crime patterns: implications for theory and policy. Journal of Research in Crime and Delinquency, 48, 58-82.

Bernasco, W. \& Steenbeek, W. (2016). More places than crimes: implications for evaluating the law of crime concentration at place. Journal of Quantitative Criminology. doi: 10.1007/s10940-016-9324-7.

Braga, A., Hureau, D.M. \& Papachristos, A.V. (2010). The concentration and stability of gun violence at micro places in Boston, 1980-2008. Journal of Quantitative Criminology, 26, 33-53.

Bruinsma, G.J.N. \& Pauwels, L.J.R. (2017). The added value of the criminology of place to the research agenda of environmental criminology: core propositions for unexplained mechanisms. In: D. Weisburd \& J. Eck (eds.). Connecting crimes to place. New directions in theory and policy. (in press)

Bunge, M. (1999). Social science under debate: a philosophical perspective. Toronto: University of Toronto Press.

Byrne, J.M. \& Sampson, R.J. (1986). The social ecology of crime. New York: Springer-Verlag.

Covington, J. \& Taylor, R.B. (1991). Fear of crime in urban residential neighborhoods. The Sociological Quarterly, 32(2), 231-249.

Dark, S.J. \& Bram, D. (2007). The modifiable areal unit problem (MAUP) in physical geography. Progress in Physical Geography, 31(5), 471-479.

Eck, J.E. \& Weisburd, D. (1995). Crime places in crime theory. In: J.E. Eck \& D. Weisburd (eds.). Crime and place. Crime Prevention Studies 4. Monsey, NY: Willow Tree Press. 
Hardyns, W., Vyncke, V., Pauwels, L.J.R. \& Willems, S. (2015). Study protocol: SWING social capital and well-being in neighborhoods in Ghent. International Journal for Equity in Health, 14(36), 1-10.

Jeffery, C.R. (1971). Crime prevention through environmental design. Beverly Hills: Sage.

Kalter, F. \& Kroneberg, C. (2014). Between mechanism talk and mechanism cult: new emphases in explanatory sociology and empirical research. KZfSS - Kölner Zeitschrift für Soziologie und Sozialpsychologie, 66(1), 91-115.

Lee, Y., Eck, J.E., O, S. \& Martinez, N.N. (2017). How concentrated is crime at places? A systematic review from 1970 to 2015. Crime Science, 6(6), 1-16.

Melo, S.N., Matias, L.F. \& Andresen, M.A. (2015). Crime concentrations and similarities in spatial crime patterns in a Brazilian context. Applied Geography, 62, 314-324.

Newman, O. (1972). Defensible space: crime prevention through environmental design. New York: Macmillan.

Oberwittler, D. \& Wikström, P.-O.H. (2009). Why smaller is better: advancing the study of the role of behavioral contexts in crime causation. In: D. Weisburd, W. Bernasco \& G.J.N. Bruinsma (eds.). Putting crime in its place: units of analysis in geographic criminology. New York: Springer Science Business Media, LLC, 36-60.

Opp, K.D. (2005). Explanations by mechanisms in the social sciences. Problems, advantages and alternatives. Mind \& Society, 4(2), 163-178.

Pauwels, L.J.R. (2002). De ene buurt is de andere niet. Exploratie van mogelijkheden tot contextualisering van geregistreerde criminaliteit op buurtniveau. Brussel: VUBPress.

Pierce, G.L., Spaar, S. \& Briggs, L.B.R. (1988). The character of police work: strategic and tactical implications. Boston, MA: Center for Applied Social Research, Northeastern University.

Reiss, A.J. \& Tonry, M. (eds.) (1986). Communities and crime: a review of research (Vol. 8). Chicago: University of Chicago Press.

Rengert, G.F. \& Lockwood, B. (2009). Geographical units of analysis and the analysis of crime. In: D. Weisburd, W. Bernasco \& G.J.N. Bruinsma (eds.). Putting crime in its place: units of analysis in geographic criminology. New York: Springer Science Business Media, LLC, 109-122.

Rummens, A., Hardyns, W. \& Pauwels, L.J.R. (2017). The use of predictive analysis in spatiotemporal crime forecasting: building and testing a model in an urban context. Applied Journal of Geography. (online first)

Sherman, L.W., Gartin, P.R. \& Buerger, M.E. (1989). Hot spots of predatory crime: routine activities and the criminology of place. Criminology, 27(1), 27-55.

Steenbeek, W. \& Weisburd, D. (2015). Where the action is in crime? An examination of variability of crime across different spatial units in The Hague, 2001-2009. Journal of Quantitative Criminology, 32(3), 449-469.

Sutherland, E.H. (1947). Principles of criminology. Chicago: University of Chicago Press.

Weisburd, D. (2015). The law of crime concentration and the criminology of place. Criminology, 53(2), 133-157.

Weisburd, D. \& Amran, S. (2014). The law of concentration of crime at place: the case of Tel Aviv-Jaffa. Police Practice \& Research, 15, 101-114.

Weisburd, D., Bernasco, W. \& Bruinsma, G.J.N. (2009a). Putting crime in its place: units of analysis in geographic criminology. New York: Springer Science Business Media, LLC.

Weisburd, D., Bruinsma, G.J.N. \& Bernasco, W. (2009b). Units of analysis in geographic criminology: historical developments, critical issues, and open questions. In: D. Weisburd, W. Bernasco \& G.J.N. Bruinsma (eds.). Putting crime in its place: units of analysis in geographic criminology. New York: Springer Science Business Media, LLC, 3-31. 
Weisburd, D., Groff, E.R. \& Yang, S.-M. (2012). The criminology of place: street segments and our understanding of the crime problem. New York: Oxford University Press.

Weisburd, D., Bushway, S., Lum, C. \& Yang, S.-M. (2004). Trajectories of crime at place: a longitudinal study of street segments in the city of Seattle. Criminology, 42(2), 283-321.

Weisburd, D., Eck, J., Braga, A., Telep, C., Cave, B., Bowers, K. e.a. (2016). Place matters: criminology for the 21st century. Cambridge: Cambridge University Press.

Wikström, P.-O.H. (2007). The social ecology of crime: the role of the environment in crime causation. In: H.-J. Schneider (ed.). Internationales Handbuch der Kriminologie. Berlin: Walter de Gruyter.

Wilcox, P. \& Eck, J.E. (2011). Criminology of the unpopular. Criminology \& Public Policy, 10(2), 473-482. 